\title{
Review
}

\section{Fear of breakdown: Politics and psychoanalysis}

\author{
Noëlle McAfee \\ Columbia University Press, New York, 2019, \\ xiv+292pp., ISBN: 9780231192699
}

Contemporary Political Theory (2022) 21, S146-S149. https://doi.org/10.1057/s41296021-00520-x; published online 6 September 2021

Breakdown is an apt word for encapsulating the present political moment. Liberal institutions are increasingly dysfunctional, and civic norms are steadily eroding in democracies old and new; social trust is disintegrating, and climate catastrophe manifests through extreme temperatures and increasingly violent floods, fires, and hurricanes. In this age of derangement, public traumas and fears - surrounding, for instance, racial or gender violence and inequities, or cultural, economic, technological, and climactic transformations - interface with psychological dramas and defenses. Psychic troubles - anxiety, depression, or paranoia - are increasingly public matters, if not directly political phenomena. For these reasons and more, Noëlle McAfee argues that political theory and praxis need psychoanalysis; not simply as a means of identifying the political pathologies attendant to breakdown but also for imagining alternatives in our troubled world.

McAfee begins with the concept of breakdown itself, as articulated by the psychoanalyst D.W. Winnicott. For Winnicott, breakdown is an experience of primordial emptiness or an 'unthinkable state of affairs' that underlies the ego's defense organizations (p. xiii). Breakdown occurs because the ego is not mature enough to 'encompass' the phenomenon of maternal rupture or able to gather 'all the phenomena' of natal separation 'into the area of personal omnipotence' (p. xiii). Breakdown, and the original repression it inaugurates, persists within the unconscious, but it is the fear of this experience - which took place prior to the establishment of an ego capable of experiencing - that can 'destroy' the individual's life (p. xiii). Therefore, Winnicott argues that patients need to be reminded that the breakdown has already happened in order to work through the unspeakable fear that the breakdown is still yet to occur. Confronting the fear of breakdown enables the construction of an ego that can bring the event into its 'present time experience,' structured by the facilitating environment provided by analysis (xiv).

(c) 2021 The Author(s), under exclusive licence to Springer Nature Limited. 1470-8914 Contemporary Political Theory Vol. 21, S4, S146-S149

www.palgrave.com/journals 
McAfee uses Winnicott's concept of breakdown to argue that there are primordial anxieties and defenses that show up not only in individual or interpersonal life but also within the public sphere. If fears of breakdown are not worked through, they will manifest in a politics characterized by what Julia Kristeva calls 'syndromes of ideality' - paranoid fantasies of perfection and demonization (p. 6). Paranoid styles of politics cannot tolerate the uncertainty, contingency, or ambivalence inherent to social life but will instead demand clear boundaries between the pure and the abject, the innocent and the damned. This Manichaean politics is a screen projected by fears of breakdown, leading to violent fantasies and, most likely, to actual violence and psychic structures that nullify feelings of guilt, empathy, or connection across differences.

Orthodox psychoanalysis, famously, was largely pessimistic about the possibilities for a nonrepressive, yet peaceful or stable, form of collective life. In Civilization and Its Discontents, Freud concluded that, due to an innate desire for aggression, 'man is a wolf to man' (homo homini lupus) (2010, p. 65). In recent decades, the so-called relational turn within psychoanalysis - represented in part by Winnicott - has challenged Freudian pessimism by arguing that humans are relational and interactive at birth (if not before), implying that aggression can be overcome or viewed as a relatively benign form of individual differentiation, as opposed to reflecting an innate desire for domination. McAfee takes something of a middle position, arguing that humans are relational and social creatures but born without a capacity to recognize this sociality. Early life is characterized by a state of 'plenum', in which self, other, and world are undifferentiated from one another, and it is the loss of plenum that inaugurates breakdown and sets in motion the twinned unconscious fantasies of a return to plentitude and the persecutory others who threaten this return. Plenum and its rupture - as unavoidable features of human life - mean that the passage to what McAfee calls reflexive sociality is both fraught and fragile (pp. 50-51).

The only antidote to a repetitive politics of trauma and violence, McAfee argues, is a psychoanalytically informed and deeply democratic politics, conceived less as a means of conflict resolution or interest group pluralism and more as a master practice for individual and collective autonomy. For McAfee, democracy properly understood consists of six key practices: imagining politics as public practice (not simply the domain of formal institutions); having a self-understanding as citizens (not subjects); identifying and thematizing problems (through the public and not simply through cognitive or social elites); deliberating with others; harnessing public will for action; learning from the past and questioning radically (pp. 8-9). In coming up with this conception of democracy, McAfee draws not only from a somewhat eclectic group of theorists including Iris Marion Young, Jürgen Habermas, Benjamin Barber, John Dewey, Hannah Arendt, Harry Boyte, and Cornelius Castoriadis, but also from her years of experience as a political activist and a deliberative practitioner. Democratic practices, for McAfee, can provide a 
public means of working through fears of breakdown and of seeing beyond breakdown toward unanticipated futures of collective freedom.

The strengths of McAfee's book begin with the straightforward way she demonstrates the relevance of psychoanalysis to democratic politics, and not only as a diagnostic tool for detecting pathologies but as a means of exploring the desires - conscious and unconscious - carried within the idea and ideals of democracy itself: the demands for voice, agency, and imagination that represent the other side of feelings of powerlessness, apathy, and persecution. McAfee's eclectic and inclusive style of writing draws from a wide range of theoretical voices and practical experiences and avoids the academic pitfall of the 'narcissism of small differences,' in which the boundaries between theorists - say, between Lacan and Winnicott - are dogmatically staked out and policed. The book is lucidly and compellingly written and will be accessible to readers unfamiliar with psychoanalysis while also engaging for specialists in democratic theory, critical theory, and psychoanalysis. It is a timely and valuable contribution to debates within political theory - and social science more broadly - concerning the rise of authoritarian populism and internal and external challenges to liberal democratic polities.

The central drawback of McAfee's analysis is that the chapters on psychoanalysis, the fear of breakdown, and plenum are relatively unintegrated with the chapters that articulate democracy as a series of interlocking practices. McAfee points to the possibilities that democratic practices of naming and framing public issues, deliberating together across differences, harnessing public will and taking action - among the other practices she lists - could effect a kind of therapeutic politics that mutes or modulates fears of breakdown, but she does not explicitly demonstrate this possibility. Some significant questions - such as whether a psychoanalytically informed politics requires new institutions or practices, or whether it is more a matter of the spirit that might animate existing practices - are not quite addressed as fully as they could be. Relatedly, McAfee has not fully wrestled with how idealization, in some form, is a necessary element of democratic life. For McAfee, idealization is problematic because it is simultaneously persecutory; it requires an abject other twinned with the idealized object. Idealization also feeds feelings of powerlessness because it invents a 'Great Other' who can, supposedly, provide absolute satisfaction. This has a debilitating effect personally and politically, since it feeds authoritarian impulses and fantasies.

Nevertheless, idealization - even on McAfee's own account as well as Winnicott's - is a necessary element of working through fears of breakdown. Winnicott argues that maternal preoccupation and the transference situation - his primary 'holding environments' - work because they enable a fantasy of omnipotence or mastery through which the individual can integrate heretofore split off elements of their internal and external worlds. Also, while it is clear that idealization defenses can show up regressively in politics, democracy seems to 
require idealization of its objects of attachment - for instance, the demos. I think Melanie Klein's concept of the 'good object' is a more productive way of engaging democratic illusions and ideals and the kinds of practices with which those ideals exist in productive tension (McIvor, 2016). Psychic and social health each requires a certain measure of idealization.

Overall, McAfee's Fear of Breakdown is an exciting contribution to work in political theory that seeks to engage with psychoanalysis without reducing the political to the psychological (or vice versa), while simultaneously maintaining a critical and historical edge against positivistic social psychology. McAfee's reading of Winnicott's concept of breakdown is an especially evocative interpretation that has implications not only for democracy's fight against autocracy but for critical race and gender studies and environmental or ecological political theory as well. After all, ecological breakdown has also already happened, both in the sense that the impacts of climate change are already occurring but also in the deeper sense that our planet has already gone through several previous mass extinctions and cataclysms. Perhaps it is not breakdown, then, that we have to worry about, but the fear of breakdown that keeps us from imagining and pursuing alternatives.

\section{References}

Freud, S. (2010) Civilization and Its Discontents. Translated and edited by J. Strachey. New York: W.W. Norton \& Company.

McIvor, D.W. (2016) Mourning in America: Race and the Politics of Loss. Ithaca, NY: Cornell University Press.

Publisher's Note Springer Nature remains neutral with regard to jurisdictional claims in published maps and institutional affiliations.

David W. McIvor

Colorado State University, Fort Collins, CO 80523, USA

david.mcivor@colostate.edu

(C) 2021 The Author(s), under exclusive licence to Springer Nature Limited. 1470-8914 Contemporary S149

Political Theory Vol. 21, S4, S146-S149 